\title{
MODEL PENDIDIKAN PESANTREN TERPADU DALAM MEMBINA KARAKTER DI ERA GLOBALISASI
}

\author{
Ahmad Zakky Mubarok \\ Universitas Ibnu Khaldun (UIKA) Bogor \\ Alqudsy89@gmail.com
}

\begin{abstract}
Abstrak
Menumbuhkan karakter merupakan salah satu tujuan yang paling utama yang harus dicapai dalam semua proses pendidikan. Oleh karena itu semua lembaga pendidikan harus memiliki model yang terbaik dalam proses internalisasi karakter kepada setiap peserta didik. Tujuan penelitian ini adalah untuk memaparkan model pendidikan karakter berbasis. Penelitian ini merupakan penelitian kualitatif dengan pendekatan deskriptifkualitatif. Objekpenelitian yang menjadi fokus analisa adalah Pondok Pesantren. Rahmaniyah Al-Islamy, Bogor, Jawa Barat. Metode yang digunakan adalah objek alamiahataunatural setting dan pengumpulan datanya dengan car aobservasi partisipisan. Hasil data olah penelitian menunjukkan bahwa Pondok Pesantren Rahmaniyah Al Islami menerapkan model pendidikan karakter berbasis integral yang mencakup aspek akidah, ruhani, jasmani dan akal. Adapun proses internalisasi karakter melalui pendekatan komprehensif, pembiasaan, keteladanan, kedisiplinan dan pembudayaan.
\end{abstract}

Kata Kunci : karakter, pesantren, integral, model pendidikan.

\begin{abstract}
Growing character is one of the most important goals that must be achieved in all educational processes. Therefore all educational institutions must have the best model in the character internalization process for each student. The purpose of this study was to describe a model of character-based education. This research is a qualitative research with a qualitative descriptive approach. The object of research that is the focus of analysis is Islamic Boarding Schools. Rahmaniyah Al-Islamy, Bogor, West Java. The method used is natural objects and natural data collection by participant observation. The results of the data if the research shows that the Rahmaniyah Al Islami Islamic Boarding School implements an integral character-based education model that includes aspects of aqeedah, spiritual, physical and intellect. The process of character internalization through a comprehensive approach, habituation, exemplary, discipline and civilization.
\end{abstract}

Keywords: character, boarding school, integral, educational model. 


\section{A. Pendahuluan}

Tantangan bangsa Indonesia semakin berat ketika dihadapkan dengan arus globalisasi. Dampak negatif globalisasi yang terjadi saat ini menjadikan manusia semakin lupa terhadap jati dirinya sebagai khalifah yang senantiasa dituntut untuk memiliki sifat-sifat terpuji, berakhlak mulia, dan menjunjung tinggi nilai-nilai kemanusiaan.

Arus globalisasi yang semakin kuat dan beragam, serta proses pendidikan yang lebih mementingkan penguasaan dimensi pengetahuan (knowledge) dan hampir mengabaikan pendidikan nilai atau moral menjadi alasan yang kuat bagi Indonesia untuk membangkitkan komitmen dan melakukan gerakan nasional pendidikan karakter (Ridwan, 2011:11). Pendidikan karakter merupakan tujuan terpenting dalam proses pendidikan. Selain sebagai wadah atau proses untuk membentuk pribadi anak agar menjadi pribadi yang baik, pendidikan karakter juga sebagai imunitas serangan pemikiran musuh-musuh Islam. Pendidikan karakter merupakan sebuah kemestian dan harus ada dalam setiap lembaga pendidikan.

Mengingat pentingnya pendidikan karakter dalam membangun jati diri bangsa yang kuat dan beradab, maka diperlukan kepedulian bersama dari berbagai pihak, baik pemerintah, masyarakat, keluarga, maupun sekolah. Selain itu, pendidikan haruslah dilihat sebagai bagian yang utuh, yang memposisikan guru, materi pelajaran yang diberikan, proses pendidikan, lingkungan rumah, sosial (masyarakat), ekonomi, dan budaya lingkungan siswa sebagai bagian yang tidak terpisahkan dalam proses pembentukan karakter (caracter building) siswa menjadi anak yang saleh (Mukhtar, 2003:15).

Lembaga pendidikan yang saat ini dianggap mampu memberikan kontribusi besar dalam proses pembentukan karakter dintaranya adalah pondok pesantren. Hal ini senada dengan pernyataan Edy Supriyono yang mengatakan bahwa kompetisi yang dapat dilakukan oleh pesantren ialah dengan turut pula ambil bagian dengan memposisikan diri dan membuktikan sebagai lembaga yang juga mampu mengakomodasi tuntutan di era globalisasi, yaitu menciptakan manusia yang tidak hanya bertakwa tapi juga berilmu, memilki SDM tinggi plus berakhlakul karimah. Penciptaan output 
seperti itulah membuat pesantren mempunyai peran dan kesempatan yang lebih besar dalam mengawal bangsa Indonesia dari derasnya arus globalisasi (Fanani dan elly, 2003:61).

Berdasarkan latar belakang tersebut yang menjadikan dasar pemikiran peneliti untuk mencoba memaparkan model pendidikan karakter di Pondok Peantren. Salah satu lembaga pendidikan yang dijadikan setting penelitian ini adalah PP. Rahmaniyah Al-Islamy Cibinong Bogor.

\section{B. Pembahasan}

Secara konsepsional, pendidikan karakter terdiri dari dua kata, yaitu pendidikan dan karakter. Dalam kamus besar bahasa Indonesia, pendidikan diartikan sebagai ( hal, cara, dan sebagainya) mendidik; dan berarti pula pengetahuan tentang mendidik, atau pemeliharaan (latihan-latihan dan sebagainya) badan, batin dan sebagainya (Rahmat, 2013:29). Adapun menurut Bahasa Arab, kata karakter sering disebut dengan istilah akhlak, yang diartikan sebagai sifat atau keadaan yang tertanam di dalam jiwa yang paling dalam yang selanjutnya melahirkan berbagai perbuatan dengan mudah tanpa memerlukan pemikiran dan pertimbangan lagi, akhlak merupakan pola tingkah laku yang mengakumulasikan aspek keyakinan dan ketaatan sehingga tergambarkan dalam perilaku yang baik (Toto, 1997:189).

Secara imperative, makna pendidikankarakter dapat diketahui melalui fungsi dan tujuan masing-masing sebagaimana yang tertuang dalam UU No. 20 Tahun 2003 pasal 3 tentang Sistem Pendidikan Nasional, yaitu Pendidikan Nasional berfungsi mengembangkan kemampuan dan membentuk watak serta peradaban bangsa yang bermartabat dalam rangka mencerdaskan kehidupan bangsa, bertujuan untuk berkembangya potensi peserta didik agar menjadi manusia yang beriaman dan bertakwa kepada Tuhan Yang Maha Esa, berakhlak mulia, sehat, berilmu, cakap, kreatif, mandiri, dan menjadi warga Negara yang demokratis serta bertanggung jawab (Ridwan, 2011:8).

Makna pendidikan karakterdalam UU Sisdiknas mengisyaratkan bahwa tujuan pendidikan adalah menyiapkan manusia yang saleh dan mampu mengembangkan potensi yang ada pada dirinya secara seimbang antara potensi ruhani, jasmani dan akal pikiran.Seseorang dapat dikatakan 
berkarakter baik jika ia mampu menampilkan perilaku-perilaku baik tanpa ada paksaan dari manapun dan terus konsisten dalam kebaikannya yang terwujud dalam perilaku kehidupan sehari-hari.

Pendidikan karakter di sekolah menjadi kebutuhan vital dalam mewujudkan generasi bangsa yang kokoh. Sekolah merupakan lembaga pendidikan selain keluarga dan lingkungan yang menjamin seseorang untuk mampu melewati tahapan perkembangannya dengan lancar dan optimal. Di sinilah, pentingnya internalisasi pendidikan karakter di sekolah secara intensifdengan keteladanan, kearifan, dan kebersamaan, baik dalam program intrakurikuler maupun ekstrakurikuler.

Satu diantara model sekolah yang terus berkembang di era globalisasi ini adalah Pondok Pesantren. Secara terminologi, Mastuhumendefinisikan pesantren sebagai lembaga pendidikan tradisional Islam untuk mempelajari, memahami, mendalami, menghayati, dan mengamalkan ajaran agama Islam dengan menekankan pentingnya moral keagamaan sebagai pedoman perilaku sehari-hari (Mastuhu, 1994:55).

Pada era globalisasi saat ini, pesantren dituntut untuk mampu menjawab tantangan perubahan zaman yag ditandai dengan kemajuan sains dan teknologi yang berbasis ideologi sekuler. Maka, dalam banyak hal sistem dan kelembagaan pesantren harus dimodernisasi dan disesuaikan dengan tuntutan pembangunan, terutama dalam aspek kelembagaan sehingga secara otomatis akan mempengaruhi terhadap penetapan kurikulum yang mengacu pada tujuan institusional lembaga tersebut.

Edy supriyono menjelaskan bahwa kompetisi yang dapat dilakukan oleh pesantren ialah dengan turut pula ambil bagian, memposisikan diri dan membuktikan sebagai lembaga yang juga mampu mengakomodasi tuntutan di era globalisasi, yaitu menciptakan manusia yang tidak hanya bertakwa tapi juga berilmu, memilki SDM tinggi plus berakhlakul karimah. Penciptaan output seperti itulah membuat pesantren mempunyai peran dan kesempatan yang lebih besar dalam mengawal bangsa Indonesia dalam menghadapi era globalisasi (Fanani, 2003:61).

Salah satu upaya yang dilakukan adalah dengan rekonstruksi lembaga dan kurikulum dari pendidikan pesantren tradisional (salaf) menjadi 
pendidikan pesantren modern (khalaf). Kelebihan yang dimiliki oleh pendidikan pesantren modern adalah perpaduan antara sistem pembelajaran tradisional dan sistem pembelajaran sekolah formal seperti SD, SMP maupun SMA. pesantren modern juga mampu menyelenggarakan sistem pendidikan pesantren berbasis terpadu atau integral.

Pesantren terpadu adalah pesantren-pesantren yang diselenggarakan berada dalam satu komplek dan dikelola secara terpadu baik dari segi kurikulum, pembelajaran, guru, sarana dan prasarana, manajemen, dan evaluasi, sehingga menjadi pesantren yang efektif dan berkualitas. Kualitas yang dimaksud adalah pesantren tersebut minimal memenuhi Standar Nasional Pendidikan (SNP) pada tiap aspeknya, meliputi kompetisi kelulusan, isi, proses pendidik dan tenaga kependidikan, sarana dan prasarana, pembiayaan, pengelolaan, penilaian dan telah menyelenggarakan serta menghasilkan lulusan dengan ciri keInternasionalan (Didin dkk, 2012 : 98).

\section{Konsep Pendidikan Integral}

Secara bahasa integral artinya menyeluruh, lengkap, terpadu, sempurna. Pengertian pendidikan integral adalah sistem pendidikan yang memadukan memadukan intelektual, moral dan spiritual. Bisa juga diartikan sebuah pendidikan yang mencakup pendidikan jasmani dan rohani (M. Dahlan, 1994 : 264).

Konsep integral yang diterapkan di pesantren akan mampu menghilangkan paradigma masyarakat yang mengatakan pesantren tidak akan mampu bersaing di era globalisasi karena hanya mengajarkan pendidikan agama. Namun sebaliknya dengan konsep integral ini, maka tidak ada lagi dikotomi antara pendidikan agama dan pendidikan umum bahkan keduanya bisa berjalan secara harmonis serta didukung oleh unsur-unsur yang terkait di dalamnya.

Model pesantren modern berbasis integral berupaya mengintegrasikan aspek ketuhanan atau keimanan ke dalam berbagai bentuk kegiatan pembelajaran, karena tujuan pertama dari pendidikan Islam adalah membentuk manusia yang beriman kepada Allah. Firman Allah dalam QS. Al-Hujurat ayat 15 yang artinya: "...sesungguhnya 
orang-orang yang percaya (beriman) kepada Allah dan Rasul-Nya, kemudian mereka berjuang (berjihad) dengan harta dan jiwa mereka pada jalan Allah. Mereka itulah orang-orang yang benar" (Dept. Agama RI, 1998 : 848).

Keterpaduan dalam berbagai keragaman aspek yang akan dicapai maka materi yang kompleks sangat diperlukan dalam proses internalisasi karakter akan tetapi tetap pada pandangan yang Islami. Dari hasil penelitian, setidaknya ada beberapa aspek terintegrasi dalam kurikulum pendidikan di Pondok Pesantrena Rahmaniyah Al-Islamy, yaitu:

Pertama, aspek akidah. Aqidah adalah fondasi seluruh bangunan. Apabila aqidah benar, maka luruslah semua aktivitas kehidupan seorang muslim. Sejarah dakwah Rasulullah mencatat bahwa pertama kali yang beliau lakukan dalam membina umat adalah menegakkan kalimat tauhid atau pembinaan aqidah dan iman.

Oleh karena itu, nilai aqidah yang benar dalam pendidikan Islam sangatlah diperlukan sehingga peserta didik mampu memahami makna syahadatain dengan hakikat-hakikat yang lurus yang berdasarkan AlQur'an dan As-Sunnah yang sesuai dengan manhaj ahlus - sunnah wal jama'ah. Aqidah menjadi sangat penting karena di dalamnya terdapat empat hal: (1) Syahadatain adalah pintu gerbang Islam; (2) Intisari ajaran Islam yang terimplementasikan dengan ibadah, akhlak, syariat, dan muamalah; (3) Azaz perubahan yang telah merubah masyarakat di masa Rasulullah dari jahiliyah menjadi Islamiyah; (4) Inti dakwah para rasul.

Kedua, aspekakhlak. Diantara aspek pendidikan yang paling diutamakan di PP. Rahmaniyah Al-Islamy ialah aspek akhlak. Akhlak saat ini menjadi komoditas yang mahal, karena manusia yang berakhlak mulia pasti akan dihargai dimanapun ia berada. Sebagaimana hadits nabi, "sesungguhnya yang terbaik di antara kalian adalah yang terbaik akhlaknya." (HR. Bukhari No. 3559).

Islam begitu memperhatikan mengenai akhlak apa yang harus dimiliki murid sebelum menuntut ilmu. Ilmu itu mendahului amal, karena ilmu merupakan pokok dan syaratnya. Sedangkan amal mengikuti ilmu, karena amal itu buah dan cabangnya (Al-Ghazali, 
1987:17). Akhlak mencakup seluruh aspek kehidupan manusia, baik yang berkaitan dengan akhlak terhadap Tuhan, sesama manusia, dan alam jagat raya. Dengan mengamalkan akhlak dalam mencari ilmu diharapkan murid dapat memperoleh keberkahan, kemudahan, kesuksesan belajar serta memiliki ilmu yang bermanfaat.

Ketiga, Aspek akal. Kemajuan peradaban manusia tidak pernah terlepas dari proses berpikir. Islam menaruh perhatian besar pada aspek ini. Kemampuan berpikir yang dimiliki manusia berguna dalam mengembangkan potensi yang tersimpan dalam jasmani dan rohani. Allah menyuruh manusia menggunakan kemampuan berpikir ini sebaikbaiknya, baik berpikir tentang diri manusia itu sendiri atau tentang alam semesta ini. Allah berfirman dalam surat Ar-Rum [30] ayat 8: "Dan Mengapa mereka tidak memikirkan tentang (kejadian) diri mereka? Allah tidak menjadikan langit dan bumi dan apa yang ada diantara keduanya melainkan dengan (tujuan) yang benar dan waktu yang ditentukan.”.

Kemampuan manusia dalam mengembangkan akalnya akan melahirkan karakter intelektualitas yang dibutuhkan oleh setiap orang dalam hubungannya dengan diri sendiri. Kemampua inilah yang akan melahirkan nilai-nilai karakter diantaranya: (1) Berpikir logis, kritis, kreatif, dan inovatifartinya seseorang akan berpikir dan melakukan sesuatu secara nyata atau logika untuk menghasilkan cara atau hasil baru dan mutakhir dari sesuatu yang dimiliki; (2) Ingin tahu artinya sikap dan tindakan yang selalu berupaya untuk mengetahui lebih mendalam dan meluas dari sesuatu yang dipelajari, dilihat, dan didengar; (3) Cinta ilmu artinya cara berpikir, bersikap, dan berbuat menunjukan kesetian, kepedulian, dan penghargaan yang tinggi terhadap pengetahuan.

Keempat, aspek jasmani. Kekuatan jasmani berarti seorang muslim memiliki daya tahan tubuh sehingga dapat melaksanakan ajaran Islam secara optimal dengan fisiknya yang kuat. Shalat, puasa, zakat dan haji merupakan ajaran dan amalan di dalam Islam yang harus dilaksanakan dengan fisik yang sehat dan kuat, apalagi perang di jalan Allah dan bentuk-bentuk perjuangan lainnya. sebagaimana pesan Rasulullah, 
"Mukmin yang kuat lebih aku cintai daripada mukmin yang lemah(H.R. muslim)"(Muhil, 2014:150).

PP. Rahmaniyah Al-Islamy tidak mengabaikan aspek jasmani dalam melaksanakan pendidikanya. Tujuan dari pendidikan ini adalah: (1) kesehatan badan dan terhindarnya dari penyakit; (2) kekuatan jasmani, ketrampilan dan (3) keuletan dan ketahanan tubuh. Karena itu, Pondok pesantren Ramhaniyah Al-Islamy memiliki program jasmani diantaranya olahraga setiap sore, pekan seni dan olahraga setiap semester ke dua, olahraga bersama setiap ahad pagi, super camp, ekstrakurikuler futsal dan basket, serta kegiatan kerja bakti setiap ahad pagi.

\section{Pendekatan Pendidikan Karakter Pesantren Terpadu}

Pendidikan tidak akan berhasil apabila tidak disertai dengan pendekatan-pendekatan pendidikan dalam penanaman karakter. Pendidik harus pandai memilih pendekatan secara arif dan bijaksana. Cara seorang pendidik terhadap anak didik akan menentukan sikap dan perbuatan. Proses pendidikan karakter di Pesantren dapat dilakukan dengan empat pendekatan, yaitu; 1) pendekatan komprehensif; 2) pendekatan pembiasaan; 3) pendekatan keteladanan dan 4) pendekatan kedisiplinan, dan 5) pendekatan pembudayaan.

Pertama, pendekatan komprehensif. Istilah komprehensifyang digunakan dalam pendidikan karakter mancakup beberapa aspek.yaitu 1)isinya harus komprehensif, meliputi semua permasalahan yang berkaitan dengan pilihan nilai-nilai yang bersifat pribadi sampai pertanyaan-pertanyaan mengenai etika secara umum. 2) metodenya harus komprehensif, artinya penanaman nilai (inkulkasi), pemberian teladan, memfasilitasi serta pengembangan keterampilan akademik dan sosial. 3) pendidikan nilai hendaknya terjadi secara keseluruhan meliputii semua proses pendidikan di sekolah. Tidak hanya dalam proses pembelajaran di kelas tetapi juga dalam kegiatan ekstrakurikuler, dalam proses bimbingan dan penyuluhan dan semua aspek kehidupan. 4),pendidikan karakter hendaknya terjadi melalui kehidupan dalam masyarakat. Selain dari keluarga yaitu orang tua melainkan juga dari organisasi-organisasi di masyarakat atau lembaga keagamaan seperti 
TPA atau TPQ, sehingga semua perlu berpartisipasi dalam penanaman pendidikan nilai guna memperbaiki karakter dan moral generasi bangsa (Zuchri, 2008: 36-37).

Kedua, pendekatan pembiasaan. Pengertian pembiasaan menurut Muhammad Rasyid Dimas adalah membiasakan anak untuk melakukan hal-hal tertentu sehingga menjadi kebiasaan yang mendarah daging, yang untuk melakukannya tidak perlu pengarahan lagi. Contohnya yang paling menonjol tentang kebiasaan dalam system pendidikan karakter di pesantren adalah ibadah-ibadah ritual seperti halnya shalat, puasa, tilawah (Rasyid, 2005:47).

Pembiasaan perilaku-perilaku baik bagi anak di pondok pesantren sangat penting, karena pembiasaan yang baik akan membentuk sosok manusia yang berkepribadian baik pula. Begitu juga dengan sebaliknya. Anak tidak seperti orang dewasa yang dapat berpikir abstrak. Anak hanya bisa berpikir konkrit. Anak kecil yang belum kuat ingatannya akan lekas melupakan apa saja yang sudah dan baru terjadi. Perhatian mereka lekas dan beralih kepada hal-hal yang baru yang disukainya (Ngalim, 1991:224).

Ketiga, Pendekatan keteladanan. Keteladanan berasal dari kata dasar "teladan" yang berarti sesuatu atau perbuatan yang patut ditiru atau dicontoh (Depdikbud, 1995:129). Dalam bahasa arab diistilahkan dengan "uswatun hasanah" yang berarti cara hidup yang diridhai oleh Allah SWT. Sebagaimana yang dicontohkan Rasulullah SAW dan telah dilakukan pula oleh nabi Ibrahim dan para pengikutnya (Shodiq, 1988 : 369).

Keteladan merupakan faktor mutlak yang harus dimiliki oleh ustadz dalam pendidikan karakter di pesantren. Keteladanan yang dibutuhkan oleh ustadz berupa konsistensi dalam menjalankan perintah agama dan menjauhi larangan-larangannya. Keteladanan ustadz sangat penting demi efektivitas pendidikan karakter. Tanpa keteladanan, pendidikan karakter kehilangan ruhnya yang paling esensial; hanya slogan, kamuflase, fatamorgana, dan kata-kata negatif lainnya. 
Sementara berkaitan dengan urgensi metode keteladan Iman Bawani sebagaimana yang dinukilkan oleh Armai Arief dalam bukunya Pengantar Ilmu dan Metodologi Pendidikan Islam mengatakan bahwa, diantara faktor yang menunjang keberhasilan pendidikan pesantren adalah: 1) Terwujudnya keteladanan pada pribadi seorang pendidik; 2) Di lingkungan pesantren terciptanya relasi yang harmonis baik antara kyai dengan kyai maupun antara kyai dengan siswa; 3) Munculnya kematangan alumni pesantren untuk terlibat dalam kegiatan peribadatan di tengah masyarakat (Armai, 2002:120-130).

Keempat, pendekatan kedisiplinan. Pendekatan kedisiplinan. Pengertian disiplin menurut Mahmud Yunus adalah kekuatan yang ditanamkan oleh pendidik untuk menanamkan jiwa tentang tingkah laku dalam pribadi murid dan bentuk kebiasaan dalam diri mereka, tunduk dan patuh dengan sebenar-benarnya pada aturan-aturan yang sesuai dengan prinsip pendidikan yang sesungguhnya yaitu inti yang dijelaskan pada setiap aktivitas sekolah (Yunus dan Bakri, 1991: 36).

Dalam kaitannya dengan kegiatan di pesantren, kedisiplinan adalah suatu sikap dan tingkah laku siswa terhadap peraturan pondok pesantren. Sebagaimana pendapat yang diungkapnya oleh andy, disiplin adalah kepatuhan seorang siswa untuk menghormati dan melaksanakan suatu system yang mengharuskan orang untuk tunduh dan patuh pada keputusan, perintah atau peraturan yang berlaku (Andi, 1995 : 25). Diantara strategi yang dilakukan dalam proses pendidikan karaker di pesantren melalui kedisiplinan yakni; 1) Menyusun jadwal kegiatan aktivitas siswa dengan baik disertai Standar Oprasionalnya; 2) Menyusun tata tertib pondok pesantren; 3) Membentuk divisi kedisplinan; 4) Memberikan penghargaan dan sanksi bagi siswa, 5) Keteladanan dari ustadz dan ustdzahnya.

Kelima, pendekatan pembudayaan. Pada dasarnya tanggung jawab pendidikan karakter adalah tanggung jawab bersama, mulai dari keluarga, sekolah, masyarakat, maupun pemerintah. Dalam konteks pendidikan karakter di pesantren, keberhasilan penanaman karakter 
sangat dipengaruhi oleh kultur dan budaya yang tumbuh diantara para pengelola dan asatidzah serta para siswa.

Setidaknya ada enam nilai dasar dalam kebudayaan siswa, yaitu: nilai teori, nilai ekonomi, nilai estetika, nilai social, nilai politik, dan nilai agama (In'am, 2010 : 68-69). Pembudayaan di PP. Rahmaniyah AlIslamy dilakukan dengan beberapa cara diantaranya : 1) budaya berbicara bahasa Arab dan inggris dalam percakapan sehari-hari; 2) budaya menjaga kebersihan di lingkungan pesantren; 3) budaya tidak berinteraksi antara siswa putra dan siswa putri; 4) budaya sholat berjama'ah di masjid; 5) budaya menghormati yang lebih tua dengan memanggil kakak kelas dengan panggilan kakak, abang, atau mas; 6) Menghilangkan istilah senioritas.

\section{Kesimpulan}

Model pendidikan karakter di PP. Rahmaniyah Al-Islamy yaitu menerapkan model pendidikan berbasis integral seperti yang tampak dalam beberapa kegiatan baik formal dan non formal. Dalam kegiatan formal seperti belajar mengajar di jam sekolah, semua guru di sekolah dituntut untuk mampu menyampaikan nilai-nilai keimanan dan akhlak disetiap materi yang diajarkan. Selain itu mereka juga diwajibkan untuk memberikan keteladan baik dari penampilan, tutur kata, dan perilaku. Ada empat pendekatan yang dapat dilakukan dalam proses internalisasi karakter, yaitu: 1) pendekatan komprehensif yang dilakukan secara menyeluruh dalam semua kegiatan; 2) pendekatan kebiasaan melalui tata tertib pesantren, teguran, arahan dan nasehat secara kontinu; 3) pendekatan keteladanan yang ditujukan kepada seluruh unsur-unsur yang terkait dlam proses pendidikan baik langsung maupun tidak langsung;4) pendekatan kedisiplinan melalui pemberian reward dan panishmen kepada siswa; 5) pendekatan pembudayaan melalui slogan-slogan kebersihan, kedisiplinan dan ibadah.

Integrasi pendidikan karakter harus tetap dijaga dan terus dikembangkan PP. Rahmaniyah Al-Islamy. Secara psikologis, mendidik anak-anak seusia SMP memberikan tantangan sekaligus peluang bagi pihak pesantren untuk menanamkan nilai intelektualitas dan akhlak Islamiyah dalam waktu bersamaan. Terlepas dari segala kekurangan dan kelemahannya, apa yang 
Ahmad

telah dikembangkan oleh PP. Rahmaniyah Al-Islamy dalam hal pendidikan integral dan pendekatan-pendekatan bisa dijadikan model oleh pesantren lain dalam upaya mengajarkan dan menanamkan nilai-nilai karakter Islami. 


\section{Daftar Pustaka}

Al-Ghazali, 1987, "Ihya Al-Ghazali Jilid VIII, terj. 'ismail ya'qub, Jakarta:

Faizah.

Al-Khin, Mustofa Said, Mustofa Al-Bugho,et.al, 2014, Syarah Dan Terjemah Riyadhus Sholihin Imam Nawawi Jld 1, terj. Muhil Dhoir, Et.Al, Jakarta: Al-I'tishom.

Arief, Armai, 2002, Pengantar Ilmu dan Metodologi Pendidikan Islam, Jakarta: Ciputat Pers.

Dahlan, M, 1994, Kamus Ilmiah Popular, Surabaya: Arkola.

Departemen Pendidikan dan Kebudayaan, 1995, Kamus Umum Bahasa Indonesia, Jakarta: Balai Pustaka.

Dimas, Muhammad Rasyid, 2005, 25 Kiat Mempengaruhi Jiwa Dan Akal Anak, Bandung: Syamil Cipta Media.

Fanani, A. Z. dan Elly El-Fajri, 2003, Menggagas Pesantren Masa Depan, Yogyakarta: Qirtas.

Hafidhuddin, Didin, Damanhuri, Endin Mujahidin, 2012, Inovasi Pengelolaan Pesantren Terpadu Dalam Meghadapi Persaingan Di Era Globalisasi, Bogor: UIKA.

Mastuhu, 1994, Dinamika Sistem Pendidikan Pesantren: Suatu Kajian Tentang Unsur Dan Nilai Sistem Pendidikan Pesantren, Jakarta: INIS.

Mukhtar, 2003, Desain Pembelajaran Pendidikan Agama Islam, Jakarta: CVMisaka Galiza.

Purwanto, M. Ngalim, 1991, Ilmu Pendidikan Teoritis Dan Praktis, Bandung: Remaja Rosda Karya.

Rasdiyanah, Andi, 1995, Pendidikan Agama Islam, Bandung: Lubuh Agung Baru,

RI, Dept. Agama, 1998. Al Qur'an Dan Terjemahannya. Surabaya: Al-

Hidayah.

Rosyadi, A. Rahmat, 2013, Pendidikan Islam Dalam Perspektif Kebijakan Pendidikan Nasional, Bogor: UIKA.

Sani, Ridwan Abdullah, 2011, Pendidikan Karakter Di Pesantren, Bandung: Citapustaka Media Perintis. 
Ahmad

Sodiq, M. 1988. Kamus Istilah Agama, Jakarta: CV. Sientarama.

Sulaiman, In'am, 2010, Masa Depan Pesantren: Eksistensi Pesantren di Tengah Gelombang Modernisasi, Malang: Madani.

Suryana, A. Toto, dkk, 1997, Pendidikan Agama Islam, Bandung: Tiga Mutiara.

Yunus, Mahmud dan Muhammad Qasim Bakri, 1991, At Tarbiyah wa Ta'lim, Juz II, Ponorogo: Darussalam Press.

Zuchri, Darmiyati, 2008, Humanisasi Pendidikan, Menemukan Kembali Pendidikan yang Manusiawi, Jakarta: Bumi Aksara. 